\title{
Hubungan tingkat aktivitas fisik dengan acute mountain sickness pada pendaki gunung
}

\author{
Tiara Permatasari, ${ }^{1}$ Nuryani Sidarta ${ }^{2}$
}

\begin{abstract}
ABSTRAK
LATAR BELAKANG

Acute mountain sickness (AMS) merupakan kelainan yang sering dialami oleh pendaki pemula di ketinggian lebih dari $2.500 \mathrm{~m}$. Menurut jurnal yang dikeluarkan oleh Military Medical Research pada tahun 2019, Murdoch mengemukakan bahwa prevalensi AMS sebesar 88.6\%. Di Indonesia, masih sangat sedikit studi dan penelitian yang membahas AMS di kalangan pendaki gunung. Pada pendaki memiliki tingkat aktivitas fisik yang baik dapat mempermudah mereka dalam melakukan suatu perjalanan pendakian gunung. Tujuan penelitian ini adalah menilai hubungan tingkat aktivitas fisik dengan acute mountain sickness pada pendaki gunung.
\end{abstract}

\section{METODE}

Penelitian dilakukan pada bulan Februari-Juni 2021 di komunitas Mapala (mahasiswa pencinta alam), dan responden yang pernah mendaki gunung dengan menggunakan desain studi cross-sectional. Tingkat aktivitas fisik diukur menggunakan kuesioner GPAQ (Global Physical Activity Questionnaire) dan derajat kejadian acute mountain sickness diukur menggunakan kuesioner LLS (Lake Louise Acute Mountain Sickness Score). Analisis menggunakan uji Chi-square dengan tingkat kemaknaan $\mathrm{p}<0.05$.

\section{HASIL}

Responden pada penelitian ini didominasi oleh kelompok usia dari 19 sampai 39 tahun dengan variasi tingkat aktivitas fisik dari kategori sedang (50\%) ke berat (40.7\%). Seluruh responden mengalami kejadian AMS dari kategori ringan (73.7\%) ke sedang (23.7\%). Pada kelompok responden yang memiliki tingkat aktivitas fisik kategori tinggi maka sebagian besar (73.3\%) diantaranya hanya mengalami AMS ringan. Sebaliknya, pada kelompok responden yang memiliki tingkat aktivitas fisik rendah maka mayoritas $(62.5 \%)$ dari mereka mengalami AMS sedang. Hasil uji Chi-square menunjukkan terdapat hubungan bermakna antara tingkat aktivitas fisik dengan AMS pada pendaki gunung $(\mathrm{p}=0.034)$.

\section{KESIMPULAN}

Terdapat hubungan antara tingkat aktivitas fisik dengan acute mountain sickness pada pendaki gunung.

Kata kunci: aktivitas fisik, acute mountain sickness, pendaki gunung
${ }^{1}$ Program Studi Kedokteran, Fakultas Kedokteran Universitas Trisakti, Indonesia

${ }^{2}$ Departemen Anatomi, Fakultas Kedokteran Universitas Trisakti, Jakarta, Indonesia

\section{Korespondensi:}

Nuryani Sidarta

Departemen Anatomi, Fakultas

Kedokteran Universitas Trisakti, Jakarta, Indonesia

Jalan Kyai Tapa (Kampus B)

Usakti, Grogol, Indonesia 11440

Email:

nuryani_sidarta@trisakti.ac.id

J Biomedika Kesehat 2021;4(3):106112

DOI: 10.18051/JBiomedKes.2021. v4.106-112

pISSN: 2621-539X / eISSN: 2621-5470

Artikel akses terbuka (open access) ini didistribusikan di bawah lisensi Creative Commons Attribution 4.0 International (CC-BY 4.0) 


\section{ABSTRACT}

\section{Relationship between level of physical activity level and acute mountain sickness in mountain climbers}

\section{BACKGROUND}

Acute mountain sickness (AMS) is a disorder that is often experienced by novice climbers at an altitude of more than 2,500m. According to a journal released by Military Medical Research in 2019, Murdoch stated that the prevalence of AMS was $88.6 \%$. In Indonesia, there are only a few studies and researches discussing AMS among mountain climbers. A good level of physical activity can make it easier for the climber to make a mountain climbing trip. The purpose of this study was to assess the relationship between physical activity levels and acute mountain sickness in mountain climbers.

\section{METHODS}

The research was conducted in February-June 2021 in the Mapala (mahasiswa pencinta alam) community and respondents who have been climbing a mountain using a study design cross-sectional. Physical activity level was measured using the questionnaire GPAQ (Global Physical Activity Questionnaire), and the level of acute mountain sickness was measured using the questionnaire LLS (Lake Louise Acute Mountain Sickness Score. Data analysis using the test Chi-square with a significance level of $p<0.05$.

\section{RESULTS}

Respondents were dominated by the age group from 19 to 39 years old with the level of physical activity vary from moderate $(50 \%)$ to severe category $(40.7 \%)$. All of the respondents experienced AMS, of which $73.7 \%$ had mild intensity and $23.7 \%$ had moderate AMS. Data showed that respondents who had a high level of physical activity $(73.7 \%)$ only experienced mild AMS. On the contrary, we found that respondents who had a low level of physical activity $(62.5 \%)$ experienced moderate AMS. The results of the Chi-square test show that there is a significant relationship between the level of physical activity and acute mountain sickness in mountain climbers $p=0.034$.

\section{CONCLUSION}

There is a relationship between physical activity level with acute mountain sickness in mountain climbers.

Keywords: physical activity, acute mountain sickness, mountain climbers

\section{PENDAHULUAN}

High altitude illness (HAI) merupakan sekumpulan gejala pada organ paru dan otak yang terjadi pada orang yang baru pertama kali mendaki ke ketinggian, termasuk di dalamnya adalah Acute Mountain Sickness (AMS), High-Altitude Cerebral Edema (HACE), dan High-Altitude Pulmonary Edema (HAPE). ${ }^{(1)}$ Acute Mountain Sickness (AMS) adalah kelainan yang sering dialami oleh pendaki pemula saat berada pada ketinggian lebih dari 2.500 meter. Tujuh puluh lima persen dari para pendaki dapat mengalami gejala ringan AMS dan kejadian AMS tergantung pada elevasi, laju pendakian, dan kerentanan tiap individu. (2) Selain itu, terdapat studi yang dilakukan pada tahun 2016 menyimpulkan bahwa kejadian AMS dapat terjadi karena pajanan mendadak terhadap ketinggian, biasanya di saat seseorang telah berada lebih dari 8000 kaki di atas permukaan laut. ${ }^{(3)}$. Data publikasi dari Military Medical Research pada tahun 2019 oleh Murdoch et al. menyebutkan angka prevalensi kejadian AMS yang cukup tinggi, yaitu sebesar $88.6 \%$ pada para pendaki di Nepal. ${ }^{(4)}$ Penelitian di Indonesia sendiri pada tahun 2019 mendapatkan angka prevalensi AMS masih tergolong rendah, yaitu sekitar $20 \%$ dari seluruh sampel penelitian yang dilakukan. ${ }^{(5)}$

AMS biasanya ditandai dengan berbagai macam gejala antara lain seperti sakit kepala, pusing, muntah, anoreksia, kelelahan, dan insomnia setelah pendakian mencapai dataran tinggi. Beberapa studi mengatakan bahwa gejalagejala tersebut dapat terjadi secara langsung atau terjadi setelah beberapa hari atau setelah beberapa minggu setelah kejadian berlangsung. Biasanya perubahan ini terjadi akibat penurunan tekanan yang sangat drastis maupun secara bertahap. (5) Selain perubahan lingkungan yang menjadi penyebab munculnya AMS, kondisi tubuh manusia itu sendiri, yaitu tingkat aktivitas fisik juga menjadi salah satu faktor yang berkontribusi. Sudah banyak penelitian yang dilakukan untuk melihat ada tidaknya hubungan antara tingkat aktivitas fisik dengan derajat AMS yang dapat dialami oleh para pendaki.

Berdasarkan penelitian pada tahun 2014 yang disampaikan oleh Richalet et al., tidak ada hubungan yang signifikan antara penyakit ketinggian dengan aktivitas fisik yang lebih tinggi karena masih terdapat faktor penyebab 
lainnya. ${ }^{(6)}$ Akan tetapi, menurut penelitian yang lain, kurangnya persiapan aktivitas fisik dan tidak adanya proses aklimatisasi, seperti tidak melakukan olahraga teratur atau pun memaksakan diri mendaki lebih dari 1000 kaki dalam satu hari dengan ketinggian $2.500 \mathrm{~m}$, membuat persentase yang muncul akan semakin tinggi dan menyebabkan kejadian AMS. ${ }^{(1)}$ Dari permasalahan tersebut, peneliti tertarik untuk meneliti apakah terdapat hubungan antara tingkat aktivitas fisik dengan kejadian AMS pada pendaki gunung di Indonesia.

\section{METODE}

Penelitian ini menggunakan desain penelitian deskriptif analitik dengan pendekatan potong lintang. Penelitian ini dilakukan pada 86 responden yang merupakan mayoritas anggota pendaki dari organisasi Mapala (Mahasiswa pencinta alam) ditambah dengan pendaki lainnya. Pengambilan sampel menggunakan consecutive non random sampling. Kriteria inklusi pada penelitian ini meliputi para pendaki laki-laki dan perempuan yang sudah pernah mendaki gunung dengan ketinggian $>2.500 \mathrm{~m}$. Responden yang memiliki kondisi seperti memiliki riwayat penyakit yang dapat mengakibatkan terjadinya hipoksia, menggunakan alat bantu jalan (tongkat, walker, kursi roda), memiliki riwayat menggunakan obat penenang atau pun sedang menjalani radio/kemoterapi, serta pendaki yang melakukan pendakian absolut (pendaki yang mendaki dengan gunung ketinggian melebihi $2.500 \mathrm{~m}$ dengan tempo pendakian yang ekstrim) akan dikeluarkan dari penelitian ini.

Pada tahap awal peneliti memberikan penjelasan terlebih dahulu mengenai tujuan penelitian serta menjelaskan pertanyaanpertanyaan yang terdapat di dalam kuesioner agar responden dapat memahami dengan benar setiap pertanyaan yang terdapat di dalam masing-masing kuesioner. Responden diingatkan untuk mengisi kuesioner dengan sejujurnya. Kuesioner yang diberikan kepada para responden adalah GPAQ (Global Physical Activity Questionnaire) untuk mengukur tingkat aktivitas fisik responden dan kuesioner Lake Louise Acute Mountain Sickness Score (LLA-AMS) untuk menilai ada tidaknya penyakit Acute Mountain Sickness (AMS).

Pada penelitian ini, pengambilan data dilakukan dengan menggunakan Google form yang disusun dengan menyesuaikan pertanyaanpertanyaan yang terdapat di dalam kuesioner tersebut. Secara keseluruhan, kuesioner ini terdiri dari 16 pertanyaan yang dibuat untuk memperkirakan tingkat aktivitas fisik seseorang pada 3 aktivitas, yaitu (pekerjaan, perjalanan, dan rekreasi). Pengukuran aktivitas fisik menggunakan GPAQ (Global Physical Activity Questionnaire) akan diklasifikasikan berdasarkan skor METs yang diperoleh. METs sendiri adalah rasio dari laju metabolisme saat kerja dibandingkan laju metabolisme saat istirahat. Nilai MET setara dengan konsumsi kalori $1 \mathrm{kkal} / \mathrm{kg} / \mathrm{jam}$. (21) Data durasi aktivitas dalam kategori berat dikaitkan dengan koefisien METs $=8$, sedangkan untuk aktivitas yang rendah dikaitkan dengan koefisien METs $=4$. Rumus yang digunakan dalam perhitungan skor aktivitas fisik adalah total aktivitas fisik METs menit/minggu $=[(\mathrm{P} 2 \mathrm{x} \mathrm{P} 3 \mathrm{x}$ $8)+(\mathrm{P} 5 \times \mathrm{P} 6 \times 4)+(\mathrm{P} 8 \times \mathrm{P} 9 \times 4)+(\mathrm{P} 11 \times \mathrm{P} 12 \times 8)$ $+(\mathrm{P} 14 \times \mathrm{P} 15 \times 4)]$. Klasifikasi penilaian aktivitas fisik menurut GPAQ dibagi menjadi 3 kategori, yaitu rendah (kurang dari 600 METs), sedang (antara 600-3000 METs) dan tinggi (lebih dari 3000 METs). Hal yang sama juga dilakukan pada pengisian kuesioner LLA-AMS yang diberikan juga dalam bentuk Google Form. di mana apabila total skor yang didapatkan adalah antara 3 sampai 4 maka dimasukkan dalam kelompok AMS ringan. Bila skor yang didapatkan antara 5 sampai 10 maka dikategorikan AMS sedang dan bila skor lebih dari 10 maka dikategorikan AMS berat.

Hasil yang didapatkan dari penelitian ini akan dianalisis dengan menggunakan analisis data univariat dan bivariat. Analisis univariat digunakan untuk menggambarkan variabel independen, yakni tingkat aktivitas fisik dan variabel dependen yakni Acute Mountain Sickness (AMS). Analisis bivariat digunakan untuk mengetahui bermakna atau tidaknya hubungan antar variabel. Analisis data menggunakan uji Chi-square dengan tingkat kemaknaan kurang dari 0.05 .

\section{HASIL}

Pada hasil penelitian didapatkan bahwa dari 86 responden populasi terbanyak didapatkan pada kelompok usia 19-30 tahun dan usia terbanyak adalah usia 20 tahun dengan jenis kelamin laki-laki menduduki populasi terbanyak. 
Sebanyak 43 responden (50\%) memiliki aktivitas fisik kategori sedang diikuti dengan $40.7 \%$ yang memiliki tingkat aktivitas dengan kategori berat. Dari 86 responden yang diteliti didapatkan sebanyak 63 responden $(73.3 \%)$ mengalami $A M S$ ringan diikuti dengan $26.7 \%$ yang memiliki AMS sedang. Tidak ditemukan responden mengalami gejala AMS berat.

Tabel 1.Distribusi karateristik responden

\begin{tabular}{lcc}
\hline Karakteristik & n & \% \\
\hline Usia & & \\
Dewasa (19-39 tahun) & 84 & 97.7 \\
Pralansia (40-65 tahun) & 2 & 2.3 \\
Jenis kelamin & & \\
Laki-laki & 55 & 64 \\
Perempuan & 31 & 36 \\
Aktivitas fisik & & \\
Rendah & 8 & 9.3 \\
Sedang & 43 & 50 \\
Tinggi & 35 & 40.7 \\
Acute mountain sickness & & \\
Ringan & 63 & 73.3 \\
Sedang & 23 & 26.7 \\
Berat & 0 & 0 \\
\hline Ket: & & \\
\hline
\end{tabular}

Ket: $\mathrm{n}=$ frekuensi; $\%=$ persentase

Untuk menilai hubungan antara tingkat aktivitas fisik dengan AMS pada pendaki gunung dilakukan analisis bivariat. Hasil analisis data tingkat aktivitas fisik dan Acute Mountain Sickness pada Tabel 2 menunjukkan bahwa pada kelompok responden yang memiliki tingkat aktivitas fisik kategori tinggi, maka sebagian besar (73.3\%) hanya mengalami AMS ringan. Keadaan yang sama juga didapatkan dari kelompok responden yang memiliki tingkat aktivitas fisik kategori sedang, maka sebagian besar (81.4\%) hanya memiliki AMS kategori ringan. Kondisi yang berbeda didapatkan dari kelompok responden yang memiliki tingkat aktivitas fisik kategori rendah, maka hanya $37.5 \%$ yang mengalami AMS ringan dan sebagian besar $(62.5 \%)$ mengalami AMS kategori sedang. Hasil ujian statistik $\mathrm{Chi}$ square didapatkan nilai $\mathrm{p}=0.034(\mathrm{p}<0.05)$. Hal ini berarti bahwa adanya hubungan yang signifikan antara tingkat aktivitas fisik dengan kejadian AMS pada pendaki gunung.

\section{PEMBAHASAN}

Penelitian yang dilaksanakan pada anggota Mapala dari setiap organisasi yang berbeda maupun orang-orang yang sudah pernah mendaki gunung memberikan hasil responden sebanyak 86 orang dengan kelompok usia terbanyak adalah dari usia 19 sampai 39 tahun dan rata-rata usia adalah kelompok usia 20 tahun. Usia memang merupakan salah satu faktor penting yang menentukan ketahanan fisik seseorang terutama saat pendakian. Keadaan fisik seseorang akan menentukan tingkat keberhasilan seseorang dalam mendaki gunung. Hal ini dikarenakan kendala umum yang dihadapi oleh pendaki gunung pada saat pendakian adalah stamina yang dapat menurun drastis pada saat mendekati puncak. Kondisi ini akan terjadi ketika tekanan udara semakin menipis serta berlanjut pada keadaan di mana pendaki sudah mulai kehilangan keseimbangan untuk mengontrol tubuh, sehingga kondisi fisik tubuh yang prima sangat dibutuhkan. ${ }^{(7)}$ Namun, sebagaimana kita tahu bahwa usia berpengaruh terhadap aktivitas fisik yang dilakukan oleh responden, dikarenakan semakin tua usia responden, maka akan cenderung lebih sedikit melakukan aktivitas fisik. ${ }^{(8)}$ Pada penelitian ini, mayoritas responden adalah berusia sekitar 20 tahun dan didapatkan memang $90.7 \%$ memiliki tingkat aktivitas fisik kategori sedang ke tinggi. Selain itu, didapatkan dua per tiga dari responden adalah berjenis kelamin lakilaki. Penelitian oleh Candrawati tahun 2011 juga menyimpulkan bahwa kelompok laki-laki cenderung memiliki tingkat aktivitas fisik yang lebih tinggi dari pada kelompok perempuan. ${ }^{(9)} \mathrm{Hal}$ ini didukung oleh penelitian Farradika, et al. di mana responden dengan jenis kelamin perempuan cenderung melakukan aktivitas fisik pasif. ${ }^{(10)}$

Menurut WHO pada tahun 2015, istilah aktivitas fisik didefinisikan seluruh pergerakan tubuh manusia mulai dari olahraga yang kompetitif sampai dengan latihan fisik sebagai hobi atau aktivitas yang dilakukan sehari-hari. ${ }^{(11)}$ Selain itu, aktivitas fisik merupakan faktor penting dari pengeluaran energi yang bermanfaat dalam menyeimbangkan energi dan kontrol berat badan bagi seseorang. ${ }^{(10)}$ WHO membagi aktivitas fisik menjadi 5 kategori utama, yaitu aktivitas bekerja, transportasi, pekerjaan rumah, olahraga, dan kegiatan rekreasi. Pengukuran tingkat aktivitas fisik dapat dilakukan dengan dua metode, yaitu pengukuran langsung dan tidak langsung. Pengukuran secara langsung dilakukan dengan menggunakan accelerometer dan pedometer untuk mendapatkan nilai METs (Metabolic Equivalent of 
Tabel 2. Hubungan antara tingkat aktivitas fisik dengan AMS pada pendaki gunung

\begin{tabular}{|c|c|c|c|c|}
\hline \multirow[b]{2}{*}{ Variabel } & \multicolumn{2}{|c|}{ Acute Mountain Sickness } & \multirow[b]{2}{*}{ Total } & \multirow[b]{2}{*}{$\mathbf{p}$} \\
\hline & $\begin{array}{c}\text { Ringan } \\
\text { n (\%) }\end{array}$ & $\begin{array}{c}\text { Sedang } \\
\text { n }(\%)\end{array}$ & & \\
\hline \multicolumn{5}{|l|}{ Aktivitas Fisik } \\
\hline Rendah & $3(37.5)$ & $5(62.5)$ & 8 & \multirow{3}{*}{$0.034 *$} \\
\hline Sedang & $35(81.4)$ & $8(18.6)$ & 43 & \\
\hline Berat & $25(73.3)$ & $1(28.6)$ & 35 & \\
\hline
\end{tabular}

*: Uji Chi-square

Tasks) secara langsung. Untuk pengukuran secara tidak langsung antara lain dengan menggunakan pengisian kuesioner. Beberapa kuesioner yang dapat dipakai untuk mengukur tingkat aktivitas fisik seseorang adalah GPAQ (Global Physical Activity Questionnaire), ${ }^{(12)}$ PAQ-A (Physical Activity Questionnaire of adolescents), ${ }^{(13)}$ Modifiable Activity Questionnaire (MAQ), ${ }^{(14)}$ Previous Week Modifiable Activity Questionnaire (PWMAQ), ${ }^{(15)}$ Recent Physical Activity Questionnaire (RPAQ), ${ }^{(16)}$ International Physical Activity Questionnaires (IPAQ), ${ }^{(17)}$ dan Previous Day Physical Activity Recall (PDPAR). ${ }^{(18)}$ Pengisian kuesioner dinilai cukup sederhana dan praktis serta dapat dilakukan oleh jumlah responden yang cukup banyak. Dalam penelitian ini, peneliti menggunakan instrumen GPAQ (Global Physical Activity Questionnaire) karena memudahkan peneliti dalam mendapatkan data dan reliabel. Selain itu, kuesioner tersebut sering dipakai oleh pemerintah dan terdaftar pada organisasi Kesehatan dunia (WHO). Instrumen GPAQ (Global Physical Activity Questionnaire) yang digunakan pada penelitian ini memiliki nilai reliabilitas kuat $0.67-0.73$. Sementara itu, berdasarkan penelitian yang dilakukan Keating et al. pada tahun 2014, nilai aktivitas fisik dari GPAQ (Global Physical Activity Questionnaire) memiliki tingkat validitas dengan data dari accelerometer $\mathrm{r}=0.48$. $^{(12)}$

Hasil penelitian menunjukkan bahwa terdapat 8 responden $(9.3 \%)$ yang memiliki nilai METs kurang dari 600 dan hal ini berarti responden tersebut masuk dalam kategori responden yang memiliki tingkat aktivitas rendah. Didapatkan jumlah persentase yang hampir sama antara jumlah antara jumlah responden yang memiliki tingkat aktivitas fisik sedang (50\%) dan jumlah responden yang memiliki tingkat aktivitas fisik tinggi (40.7\%). Dari aspek fisiologi tubuh, kegiatan mendaki gunung memang merupakan jenis aktivitas fisik yang termasuk dalam kategori berat. Para pendaki gunung harus memiliki performa fisik yang baik untuk melakukan suatu pendakian tanpa cepat mengalami kelelahan. Selain itu, terdapat adaptasi dari organ-organ tubuh terhadap perubahan tekanan udara karena perubahan ketinggian dari permukaan laut. Oleh karena itu, seorang pendaki memang dituntut untuk memiliki tingkat aktivitas fisik yang baik agar dapat melakukan pendakian ${ }^{(19)}$

Hasil penelitian ini juga menunjukkan hal yang sama dengan penjelasan di atas di mana didapatkan hampir sebagian besar para pendaki yang masuk dalam studi ini memiliki tingkat aktivitas fisik kategori sedang ke tinggi. Penemuan ini sesuai dengan hasil penelitian yang dilakukan Octaviani et al., bahwa aktivitas fisik kategori sedang lebih banyak dibandingkan aktivitas ringan dan berat. ${ }^{(20)}$ Penelitian oleh Farid et al. juga menyatakan bahwa selain melakukan persiapan sebelum pendakian, sebagian besar para pendaki juga memiliki tingkat aktivitas kategori sedang. ${ }^{(21)}$

Acute Mountain Sickness (AMS) merupakan suatu penyakit yang disebabkan karena ketidakmampuan tubuh untuk beradaptasi terhadap ketinggian. Hal tersebut timbul akibat pendakian cepat tanpa adanya adaptasi tubuh terhadap tekanan yang berbeda gunung. Diketahui bahwa hipoksia merupakan penyebab utama dari AMS. Tingkat keparahan penyakit tersebut sangat berkaitan dengan kecepatan pendakian dan tinggi maksimal yang dicapai. Biasanya individu dengan penyakit penyerta (seperti diare dan infeksi saluran napas atas) memiliki potensi lebih besar mengalami AMS. ${ }^{(22)}$ Sakit kepala masih menjadi ciri khas pada AMS yang meliputi sakit kepala berdenyut, bilateral, dan pada bagian frontal. Hal ini diperburuk pada pagi hari, dalam posisi telentang, dan juga karena olahraga berat. ${ }^{(23)}$ Terdapat berbagai cara untuk mengetahui ada 
tidaknya kejadian AMS pada seorang pendaki, antara lain melalui pemeriksaan fisik langsung dan pemeriksaan penunjang untuk menegakkan diagnosis ada tidaknya AMS pada seseorang. Namun, dapat juga dilakukan penilaian yang bersifat skrining dengan menggunakan kuesioner yang sudah divalidasi.

Pada penelitian ini, penulis menggunakan kuesioner Acute Mountain Sickness-Lake Louise Scoring (AMS-LLS). Kuesioner ini dinilai cukup mudah untuk diaplikasikan dan memiliki tingkat validitas yang baik sebagai instrumen skrining untuk melihat ada tidaknya AMS pada seorang pendaki. ${ }^{(24)}$ Dalam penelitian ini, kuesioner AMSLLS yang digunakan hanya meliputi pertanyaanpertanyaan seputar ada tidaknya gejala-gejala tertentu tanpa pertanyaan yang membutuhkan pemeriksaan fisik. Pertanyaan-pertanyaan tersebut meliputi sakit kepala sebagai keluhan utama dan gejala-gejala lainnya berupa gangguan pencernaan, kelelahan, oyong, dan gangguan tidur. Tiap jawaban akan mendapatkan skor sesuai dengan ketentuan yang telah ditetapkan. Peneliti kemudian akan menjumlah nilai akhir yang diperoleh sesuai dengan jawaban dari para responden. Bila seorang responden mendapatkan nilai total kurang dari 2 maka tidak memiliki AMS. Namun, bila skor antar 3 sampai 4 maka dikelompokkan dalam AMS ringan, bila skor antara 5 sampai 10 maka dikelompokkan dalam AMS sedang, dan bila skor lebih dari 10 maka dimasukkan dalam AMS berat.

Pada penelitian ini didapatkan seluruh responden $(100 \%)$ menunjukkan adanya gejala AMS kategori ringan dan sedang. Tidak ditemukan responden yang mengalami AMS berat. Prevalensi hampir sama dengan yang dilaporkan oleh Murdoch et al. dari Military Medical Research pada tahun 2019 yang menemukan AMS sebesar $88.6 \%{ }^{(4)}$ Namun, prevalensi studi ini menunjukkan lebih tinggi bila dibandingkan dengan hasil penelitian yang dilakukan oleh Gonggalanzi et al. pada tahun 2016 yang melaporkan bahwa 51\% pekerja konstruksi mengalami AMS saat pertama kali tiba pada ketinggian di jalur kereta Tibet dan prevalensi AMS setelah naik ke ketinggian telah dilaporkan bervariasi antara 9 dan $84 \% .{ }^{(25)}$ Dari semua peserta yang mengalami AMS maka pada studi ini didapatkan sebagian besar diantaranya (73.7\%) mengalami AMS diikuti dengan 23 responden $(26.7 \%)$ responden yang mengalami AMS sedang. Hasil ini selaras dengan hasil penelitian yang dilakukan oleh Su Lan Yang, et al. yang menyatakan bahwa kejadian AMS pada pendaki gunung Kinabalu, mayoritas mengalami AMS ringan, dan AMS sedang menduduki posisi kedua. AMS berat tidak ditemukan pada penelitian tersebut. ${ }^{(26)}$

Penelitian yang dilakukan oleh Marion McDevitt, et al. memiliki hasil yang sama, di mana pada pendaki gunung Nepal Himalaya, prevalensi AMS ringan lebih banyak dibandingkan sedang. (27) Beberapa hal yang memengaruhi mengapa gejala AMS lebih banyak dalam kategori ringan dan sedang yaitu karena semakin banyaknya edukasi tentang AMS. Sehingga pendaki sudah melakukan persiapan dan pelatihan sebelum melakukan pendakian serta meningkatkan teknologi kedokteran membuat para pendaki cepat mendapatkan pertolongan saat mengalami gejala AMS. Penelitian lainnya menunjukkan kurangnya persiapan aktivitas fisik dan tidak adanya proses aklimatisasi, seperti tidak melakukan olahraga teratur, diet makanan tinggi karbohidrat atau pun memaksakan diri mendaki lebih dari 1000 kaki dalam satu hari dengan ketinggian $2500 \mathrm{~m}$, maka persentase yang muncul akan semakin tinggi dan menyebabkan penyakit AMS. ${ }^{(1)}$ Sehingga persiapan untuk melakukan aktivitas fisik sangat diperlukan bagi para pendaki.

Hasil analisis data tingkat aktivitas fisik dan AMS didapatkan pada kelompok responden yang memiliki tingkat aktivitas fisik kategori tinggi, maka sebagian besar (73.3\%) hanya mengalami AMS ringan. Namun, sebaliknya pada kelompok yang memiliki tingkat aktivitas rendah maka lebih banyak yang mengalami AMS sedang (62.5\%) dibandingkan dengan banyaknya yang mengalami AMS ringan (37.5\%).. Analisis data pada penelitian ini menggunakan uji Chi-Square memberikan hasil nilai $\mathrm{p}=0.034$ berarti adanya hubungan bermakna antara tingkat aktivitas fisik dengan Acute Mountain Sickness pada pendaki gunung. Nilai ini memberikan arti bahwa semakin tinggi aktivitas fisik yang dilakukan oleh seorang pendaki maka prevalensi pendaki yang mengalami AMS ringan lebih besar daripada AMS sedang dan berat. Mayoritas responden yang memiliki tingkat aktivitas sedang dengan tingkat AMS ringan dikarenakan mereka sehari-hari hanya 
berjalan kaki maupun bersepeda. Selain itu, pada saat ingin mendaki, persiapan yang dilakukan sangat baik, hal tersebut dapat meminimalisir penyakit dari AMS. Hasil yang dimiliki bisa menjadi pertimbangan bagi para pendaki dalam mengoptimalkan keselamatan sebelum pendakian untuk memberikan pemahaman terkait pentingnya aktivitas fisik sebelum mendaki agar terhindar dari kejadian AMS. Pendaki dapat mencari informasi secara mandiri atau dari orang lain untuk melihat pencegahan AMS yang esensial, contohnya dengan mengetahui gejala, penanganan yang baik, dan membatasi kecepatan pendakian sesuai dengan guideline untuk mengurangi kemungkinan para pendaki mengalami AMS.

Farid Prasetyo, et al. melalui penelitiannya juga menyatakan bahwa dengan melakukan persiapan fisik sebelum mendaki gunung dapat ditinjau dari aktivitas fisik, semakin tinggi aktivitas yang disiapkan maka akan mengurangi prevalensi AMS. ${ }^{(21)}$ Dengan memiliki tingkat aktivitas fisik yang baik maka diharapkan seorang pendaki memiliki tingkat kebugaran yang baik terutama untuk efisiensi pemakaian oksigen dalam tubuh. Sebagaimana kita tahu bahwa di saat AMS menyerang tubuh, maka akan terjadi penurunan tekanan barometrik dan berkurangnya $\mathrm{PaO} 2$ secara bertahap. Seiring bertambahnya ketinggian akan mengakibatkan terjadinya peningkatan pada ventilasi saat istirahat serta kebutuhan oksigen otot juga akan meningkat. Pertukaran gas dan aliran oksigen memengaruhi pertukaran yang terjadi pada paru-paru. Penurunan kadar oksigen dalam tubuh akan menurunkan kandungan oksigen dalam darah. Penurunan $\mathrm{PaO} 2$ ini juga mengakibatkan saturasi oksigen dalam tubuh berkurang, sehingga pada saat mendaki tubuh memerlukan konsumsi oksigen yang lebih banyak dibandingkan biasanya. ${ }^{(28)}$ Memiliki tingkat kebugaran yang baik akan berarti bahwa tubuh dapat lebih efisien dalam menggunakan oksigen yang tersedia di dalam darah.

Penelitian yang dilakukan oleh Richalet et al. pada tahun 2014 menyimpulkan tingkat aktivitas fisik tidak hanya menjadi faktor penentu tunggal dalam hubungannya dengan gejala AMS. Namun, dikatakan bahwa terdapat faktor lain yang juga memberikan pengaruh terhadap timbulnya gejala AMS, seperti migrain, penggunaan acetazolamide, dan lokasi geografis. ${ }^{(5)}$
Keterbatasan pada penelitian ini adalah kurangnya pengukuran akan variabel lain yang dapat juga menjadi faktor yang memengaruhi penyakit AMS, seperti lokasi geografis, riwayat penyakit yang lain, durasi tidur, kecemasan, pengetahuan, dan lain-lain. Oleh karena itu, peneliti menganjurkan penelitian ini dilanjutkan dengan penelitian berikutnya yang lebih melibatkan faktor lain yang juga berpengaruh terhadap munculnya gejala AMS. Serta sebaiknya dilakukan pengukuran secara objektif baik untuk pengukuran tingkat kebugaran tubuh maupun penegakan diagnosa untuk AMS serta kategori tingkat gejalanya.

\section{KESIMPULAN}

Berdasarkan hasil yang didapat dari penelitian ini maka didapatkan prevalensi pendaki gunung yang mengalami AMS yaitu 100\% dengan pembagian 63 responden $(73.3 \%)$ mengalami AMS derajat sedang dan 23 responden (26.7\%) mengalami AMS derajat ringan. Penelitian ini juga menyimpulkan adanya hubungan yang bermakna antara tingkat aktivitas fisik dengan kejadian AMS pada para pendaki gunung.

\section{REFERENSI}

1. Elvira D. High-Altitude Illness. J Kesehat Andalas. 2015;4(2):582-89. doi: 10.25077/jka.v4i2.304

2. Ariyanto Y, Pradibta H, Permatasari C. Diagnosa AMS: Sistem Pakar Untuk Pendaki Gunung. J Simantec [Internet]. 2017;6(2):47-54. Available from: https://journal.trunojoyo.ac.id/simantec/ article/view/3706

3. Sikri G, Srinivasa AB, Bhutani S. Acute mountain sickness and oxygen saturation. Sleep Breath. 2016;20(3):1075-6. doi: 10.1007/s11325-0161324-1.

4. Murdoch DR. Altitude Illness Among Tourists Flying to 3740 Meters Elevation in the Nepal Himalayas. J Travel Med. 1995;2(4):255-256. doi: 10.1111/j.1708-8305.1995.tb00671.x.

5. Nurajab, E. Hubungan Tingkat Kebugaran Jasmani dengan Aklimatisasi Pendaki Gunung. J Olahraga. 2019;5(1):73-9. doi: 10.37742/jo.v5i1.97

6. Richalet JP, Larmignat $P$, Poitrine $E$, et al. Physiological risk factors for severe high-altitude illness: a prospective cohort study. Am J Respir Crit Care Med. 2012;185(2):192-8. doi: 10.1164/ rccm.201108-1396OC.

7. Meivita DN, Utomo SB, Supeno B. Rancangan Bangun Alat Ukur Kondisi Kesehatan Pada Pendaki Gunung Berbasis Fuzzy Logic. SNATi [Internet]. 2016:13-8. Available from: https:// journal.uii.ac.id/Snati/article/view/6235

8. Sari ADK, Wirjatmadi B. Hubungan Aktivitas Fisik dengan Kejadian Konstipasi Pada Lansia di Kota Madiun. J. Media Gizi Indonesia. 2016;11(1):40-7. doi: 10.20473/mgi.v11i1.40-47

9. Candrawati S. Hubungan Tingkat Aktivitas Fisik 
dengan Indeks Massa Tubuh (IMT) dan Lingkar Pinggang Mahasiswa. J Keperawatan Soedirman [Internet]. 2011;6(2):112-18. Available from: http://jks.fikes.unsoed.ac.id/index.php/jks/article/ view/335

10. Farradika Y, Umniyatun Y, Nurmansyah MI, et al. Perilaku Aktivitas Fisik dan Determinannya pada Mahasiswa Fakultas Ilmu - Ilmu Kesehatan Universitas Muhammadiyah Prof. Dr. Hamka. ARKESMAS. 2019;4(1):134-142. doi: 10.22236/ arkesmas.v4i1.3548

11. World Health Organization. Obesity and overweight [Internet]. World Health Organization; 2021 Jun 9. Available afrom: https://www.who. int/news-room/fact-sheets/detail/obesity-andoverweight.

12. Keating XD, Zhou K, Liu X, et al. Reliability and Concurrent Validity of Global Physical Activity Questionnaire (GPAQ): A Systematic Review. Int J Environ Res Public Health. 2019;16(21):4128. doi: 10.3390/ijerph16214128.

13. Wyszyńska J, Matłosz P, Podgórska-Bednarz J, et al. Adaptation and validation of the Physical Activity Questionnaire for Adolescents (PAQ-A) among Polish adolescents: cross-sectional study. BMJ Open. 2019;9(11):e030567. doi: 10.1136/ bmjopen-2019-030567.

14. Kriska AM, Knowler WC, LaPorte RE, et al. Development of questionnaire to examine relationship of physical activity and diabetes in Pima Indians. Diabetes Care. 1990 Apr;13(4):40111. doi: 10.2337/diacare.13.4.401.

15. Pettee Gabriel K, McClain JJ, Schmid KK, et al. Reliability and convergent validity of the pastweek Modifiable Activity Questionnaire. Public Health Nutr. 2011;14(3):435-42. doi: 10.1017/ S1368980010002612.

16. Besson H, Brage S, Jakes RW, et al. Estimating physical activity energy expenditure, sedentary time, and physical activity intensity by self-report in adults. Am J Clin Nutr. 2010;91(1):106-14. doi: 10.3945/ajen.2009.28432

17. Craig CL, Marshall AL, Sjöström M, et al. International physical activity questionnaire: 12-country reliability and validity. Med Sci Sports Exerc. 2003;35(8):1381-95. doi: 10.1249/01. MSS.0000078924.61453.FB.

18. Weston AT, Petosa R, Pate RR. Validation of an instrument for measurement of physical activity in youth. Med Sci Sports Exerc. 1997;29(1):138-43. doi: 10.1097/00005768-199701000-00020.

19. Wagner PD. Limiting Factors of Exercise Performance. The German Journal of Sports Medicine [Internet]. 2010;61(5):108-11. Available from: https://www.germanjournalsportsmedicine. com/archiv/archiv-2010/heft-5/limiting-factorsof-exercise-performance/

20. Oktaviani WD, Saraswati LD, Rahfiludin MZ. Hubungan Kebiasaan Konsumsi Fastfood,Aktivitas fisik, Pola Konsumsi, Karakteristik Remaja dan Orang Tua dengan Indeks Massa Tubuh (IMT). J. Kesehatan Masyarakat. 2012;1(2):542-53.

21. Putra FPM, Setyaningsih P, Santoso DA. Analisis Persiapan Fisik Pendakian Gunung Ijen dan Gunung Ranti Di Kabupaten Banyuwangi. J. Pendidikan Jasmani [Internet]. 2020;1(2);80-93. Available from: https://jurnal.stokbinaguna.ac.id/ index.php/JPJ/article/view/134

22. Maggiorini M. Prevention and treatment of highaltitude pulmonary edema. Prog Cardiovasc
Dis. 2010;52(6):500-6. doi: 10.1016/j. pcad.2010.03.001.

23. Schneider M, Bärtsch P. Characteristics of Headache and Relationship to Acute Mountain Sickness at 4559 Meters. High Alt Med Biol. 2018;19(4):321-328. doi: 10.1089/ham.2018.0025.

24. Jean Paul Richalet, Chantal Julia, Franchois J. Evaluation of Lake Louis Score for Acute Mountain Sickness and its 2018 version in cohort of 484 Trekker at High Altitude. High Altitude Medicine \& Biology. 2021;00(00):1-9. DOI: 10.1089/ham.2020.0226

25. Gonggalanzi, Labasangzhu, Nafstad P, et al. Acute mountain sickness among tourists visiting the high-altitude city of Lhasa at $3658 \mathrm{~m}$ above sea level: a cross-sectional study. Arch Public Health. 2016;74:23. doi: 10.1186/s13690-016-0134-z

26. Yang SL, Ibrahim NA, Jenarun G, et al. Incidence and Determinants of Acute Mountain Sickness in Mount Kinabalu, Malaysia. High Alt Med Biol. 2020;21(3):265-72. doi: 10.1089/ham.2020.0026.

27. McDevitt M, McIntosh SE, Rodway G, et al. Risk determinants of acute mountain sickness in trekkers in the Nepali Himalaya: a 24-year followup. Wilderness Environ Med. 2014;25(2):152-9. doi: 10.1016/j.wem.2013.12.027.

28. Hou YP, Wu JL, Tan C, et al. Sex-based differences in the prevalence of acute mountain sickness: a meta-analysis. Mil Med Res. 2019;6(1):38. doi: 10.1186/s40779-019-0228-3. 